\title{
Slack Resource as Evolutionary Determinant of International Manufacturing Joint Venture's Growth Performance
}

\author{
Stig B. Taps, Thomas Ditlev Brunø, Kjeld Nielsen, and Kaj A. Joergensen \\ Department of Mechanical and Manufacturing Engineering, Aalborg University, Denmark \\ taps@m-tech.aau.dk
}

\begin{abstract}
At present time in a world of change our understanding are constantly challenged with new knowledge that radically makes demand on prevailing theories and concept the scientific world for long have believed was unchangeable.

This article makes a back flash on innovation performance with some suggestion on how International Manufacturing Joint Ventures can enhance their learning capacity.

Manufacturing in a global world is a complicated management challenge because the supply chain is located in different national settings. Networkning and knowledge absorption is a key to get international competitiveness.

This paper claims a framework for building absorption capacity in international manufacturing firms.
\end{abstract}

Keywords: Growth performance, Innovation conceptualization, Slack resources, Absorptive capacity.

\section{Introduction}

International Manufacturing Joint Ventures (IMJV) is an organizational entity, constructed by two or more firms of different nationality [11], pooling a portion of their resources within a common legal organization [12]. These resources comprise firmspecific knowledge, and the knowledge base created in the entity is affected by each partner's sharing of knowledge with the other (Buckley, 1996). Productive resources of human technologies and mechanical technologies [5] are bundled from different sources, i.e., from partner transfer, by acquisition, and by engagement. Physical facilities are acquired, and technological equipment arrives, and is installed according to the focus. Managers, technical experts and labor are engaged, bundled together in a firm without a history by the simple fact that the IMJV is a new firm construct, a new 'child', to stand alone, and seeking to its own performance s through efficiency of combining those diverse bundling of resources. The IMJV is a synthetic organization [25], simultaneously establishing a structure and carry on operation. People have fragmented knowledge on parts of the focus, and the knowledge technology embedded in people is diffused and distinct, and acquired in working experiences from 
different organizational settings, maybe too, from other geographical locations outside the IMJV. Taking actions and making decisions within this newly structured 'child' are not supported by common understandings of actors or by common social and technological experiences.

How can such a synthetic construct growth?

Managers' must transform the IMJV from a synthetic organization through a process implying entrenched behaviors to stabilize organizational continuity whether as deliberate plans to establish patterns of behavior or as emergent patterns by which such patterns get established [16]. Accordingly the transformation process can be one of designing formal planning systems to imply entrenched organizational behavior through standardization of work, skills or outputs; and by focusing on collective socialization and individual cognition to establish an emergent pattern of coherence in behavior. Inter-correlation drive different parts in organization to coherence among their parts by means of manager's "tuning" of coordination mechanisms e.g., their choice among mechanisms to entrench behaviors in desired outcome and synergistic complementation between mechanisms.

Further, this dynamic capability approach acknowledge that resource endowments are "sticky", firms are to some degree stuck with what they have and may have to live with what they lack [24]. Features as bundling of resources, structural form of IMJV, appointment of managers to various departmental responsibility, and strategic direction are commended contractual agreements among partners' founding conditions and therefore sticky for managerial actions within IMJV. Such imprinted stickiness makes demand on the ability of an IMJV to grow and innovate. Conditions could be barriers to transfer best practice inside the firm e.g., difficulty to transfer knowledge among subunits, and be hindering to integration and operational streamlining of practices, structures and systems.

The paper is organized in the following way. First, grow performance is elaborated from an innovative perspective and it is argued that building organizational slack resources to handle uncertainty influence firm's innovative performance. Second, a constructive approach for research in management capabilities to exploit resources for innovative purpose is argued.

\section{Innovative Performance}

Innovation has been conceptualized in many ways and studied from several perspectives. For instance, distinctions are made between studies of adoption and diffusion of innovations and at different levels of analysis: individual, organizations, industry and nations.

\subsection{Economists}

Economists conceptualize innovation at a high level of aggregation or abstraction, seeing it as one of the factors that cause increased productivity and economic growth at the industry or even national level [7]. 
According to Urabe [26]:

Innovation consists of the generation of a new idea and its implementation into new product, process or service, leading to the dynamic growth of the national economy and the increase of employment as well as to creation of pure profit for the innovative business enterprise.

Firm is innovative only when 'newness' is transformed to economic benefit to society. Firm's innovativeness and rent generation are the outcome of the analytical fit between structure-conduct-performance of firms [2]. But when there are rapid changes in technology and market forces and defensible feedback effects from competitors such a monopoly rent generating strategy is difficult to defend. The growing uncertainty in today's turbulent competitive environment together with customers changing and unpredictable demand after products and services, accelerating pace of technological change affecting newness in manufacturing processes. For example, Pine claims [20] that our understanding of the market and the marketing concept is a misunderstanding because the market only exists as an individualist. Understanding customers idiosyncratic needs by development of a solution space makes increasing demand on robust process design [17].

\subsection{Technologists}

By technology researchers innovation is defined as a continuous process during which the innovation changes form as it is used and assimilated [21]. The processes of generating new technology and improving upon existing technology concern technologists and they study both product and process innovations from this perspective. Some technologists study the nature and dynamics of technological change within the context of the industry and attempt to understand the relationship between technological changes at the industry level and firm-level adaptations to these changes [1].

Other technologists researcher are concerned with factors that influence the generation of technological innovation at the level of organizational subunits such as the R\&D or the manufacturing departments. They focus on factors that improve technical performances and criteria that influence the choice and use of technological innovations in various organizational subunits.

Thus, both generation factors and adoption phases of the innovation process within subunits is under study. For example, Salvador [22] proposes a process model approach based on three fundamental organizational capabilities: Solution Space development, Robust Process Design, and Choice Navigation that constitutes radical innovation to crack the code of mass customization. Wheelwright \& Clark [28] argue that problem $\mathrm{s}$ in new product and new process development arises because of mismatch between anticipated benefits in resource utilization, organizational renewal and market position with strong defensible competitive barriers. They find causes for these mismatches from organization's analytical capability to alignment of external reality, and from lack of communication among functions within an organization and from locking into product and processes without innovative uniqueness and from managers fail to plan sufficiently. 


\subsection{Sociologists}

Also sociologists research in innovation at the focus on the organizational features that are compatible with the adoption of innovation within the organizations. One definition of innovation within this school is that innovation is adoption of an internally generated or purchased device, system, policy, program, process, product, or service that is new to the adopting organization [6].

This school studies factors (as technologists) but factors as the importance of distinct contextual, structural and individual features that explain variance in innovation adoption at the level of organization. Hage [10]claim that complexity of the division of labor is critical for organizational innovation because the division would lead to much greater adaptiveness or flexibility of the intellectual or problem-salving capacities or learning capacities of the organization, what Cohen \& Levintahl [4] refer to as absorptive capacity.

From the above discussion innovation is conceptualized in different ways. Innovation is seen as a product; a new idea; method or device and as a process of introducing something new, newness either as technology or as organization. Organization can either be generator or adopter on innovation. Organization as generator of innovation is linked to the organization's problem solving and decision making capability to remove ambiguities between successive stages of the innovation process: idea generation, project definition, problem-solving, design and development, and commercialization of new product $\mathrm{s}$ and processes.

\section{The Level and Type of Analysis}

The level of analysis is conceptualized differently across four levels: industry, organization, subunits and the innovation itself. At the industry level researcher are concerned with factors that distinguish innovation development patterns among industries such as technological appropriateness to the stages of the industry life-cycle. Research at the organizational level seeks to identify contextual, structural and behavioral characteristics that differentiate innovative from non-innovative organizations. They try to find group of organizational characteristics which relative more efficiently determine the outcome of organizational innovation such as its adaptability to the environment, capacity to allocate resources to innovative programs and overall performances. At the subunit level researcher try to identify and analyze factors that either facilitate or hinder innovations within a division or a department. The most widely studied organizational subunits are R\&D departments.

The type of innovation under investigation also differs. Process innovations are defined as tools, devices, and knowledge in throughput technology that mediate between inputs and outputs and are new to an industry, organization or subunit. Product innovations, in contrast, are outputs or services that are developed to the benefit of customers.

Type of innovation is also conceptualized as either radical or incremental. Radical innovations changes fundamentally existing practices within an organization or an industry into new practices on how to make activities around in transforming 
competences to new standards. Radical innovations give rise to new business possibilities, new strategies and new structures under increased environmental uncertainty. Incremental innovation improves the old product or process within the existing structure and strategy and mainly reinforces the existing capabilities of the organization's practices.

Type of innovation can be viewed as either technical or social. This distinction reflects a more general distinction between technical innovation and administrative innovation. Technical innovation includes products, processes and technologies used to produce products or render services related to the technical core of an organization. Administrative innovation is related to management processes in designing organizational structure, administrative processes and human resources.

Differences in conceptualization of innovation among economists, technologists and sociologists are summarized in table 1. Each group is only addressing a limited aspect of innovation complexity whenever the position is focused and broad definition, and the product and process view $s$ and the radical or incremental perspective.

At the introduction we argued that dynamic capabilities are the key role in adoption, integrating and configuring internal and external organizational skills, resources and functional competences and are important determinants for IMJV's growth performance. Therefore in the next section the focus is on the organizational level of analysis. The insights from other levels of analysis are gained to broaden the following argumentation about slack resource availability in organization as important determinants for IMJV's innovation.

\section{Slack Resources, Absorptive Capacity to Innovation}

The slack serves as a buffer between organization and environmental discontinuities and provides the organization with the internal capability to invest for innovation [8]. Evans[9] has labeled innovative capability as strategic flexibility keeping the organization both agile and versatile. Bugelman [1] argue that the rate which mutant ideas were pursued seemed to depend on the amount of slack resources available at the

Table 1. Differences in conceptualization of innovation among economists, technologists and sociologist (Based [1])

\begin{tabular}{|c|c|c|c|}
\hline & Stage of Process & Level of Study & Type of Innovation \\
\hline Economists & $\begin{array}{l}\text { Idea generation } \\
\text { Adoption }\end{array}$ & Industry & $\begin{array}{c}\text { Product, process } \\
\text { Only technical } \\
\text { Only radical }\end{array}$ \\
\hline Technologists & $\begin{array}{c}\text { Commercialization } \\
\text { Diffusion } \\
\text { Adoption }\end{array}$ & Industry context & $\begin{array}{c}\text { Product, process } \\
\text { Only technical } \\
\text { Radical, incremental }\end{array}$ \\
\hline Sociologists & $\begin{array}{c}\text { Adoption } \\
\text { Initiation } \\
\text { Implementation }\end{array}$ & Organisation & $\begin{array}{l}\text { Product and process } \\
\text { Technical, administrative } \\
\text { Radical, incremental }\end{array}$ \\
\hline
\end{tabular}


operational level. To keep it simple, we define slack as the pool of resources in an organization that is in excess of the minimum necessary to produce a level of organizational output [18]. The excess of absorptive capacity an organization on a given time has over the capacity to run the daily operation is the resource available to innovative performance.

A firm's absorptive capacity is defined as the ability prior related knowledge confers to recognize the value of new information, assimilate it, and apply it to commercial ends [4]. These abilities, collectively, constitute what they call a firm's absorptive capacity. They view absorptive capacity, at the firm level construct, as an ability the firm develops over time by accumulating a base of knowledge. The firm absorptive capacity is generated in a variety of ways: by product of a firm's R\&D activities; by production experience, reorganize or automate particular manufacturing processes; and by investment in absorptive capacity directly, when sending personal for technical training.

How manager design the structural features of the institutional, managerial, and technical level [19] of a firm, and how they coordinate interrelated activities to a coherent whole, have great influence on a firm's absorptive capacity. This design process is complicated by the resource bundling, in so far as, an IMJV is a new "child", with people without experience in working together, and with prior knowledge acquired in variety of different organizational contexts. Knowledge may be nominally acquired, but not well utilized, because the individual do not possess the appropriate contextual knowledge necessary to make new knowledge fully intelligible [14]. Therefore, firm's absorptive capacity is not simply the sum of the absorptive capacities of its employees, but is dependent on the firm's capacity to transfer knowledge across and within subunits.

In the following section we shall shortly argue a complete theoretical framework we propose to be.

\section{Theoretical Framework}

Bundling of complex, heterogeneous resources, and capabilities of organizations that are usually dissimilar in culture, size, industry, an often country of origin present a managerial challenge. Because of partners' bundling of complementary resources, management within IMJVs typically lacks administrative tools. The organization is operated by people, who do not have a common tradition, and the organization does not form an entity. Lack of planning systems or blueprints force management to establish new structures and simultaneously carry on operations. Uncertainty is high on, how to manage an IMJV to a coherent whole entity. Because of the bundling of resources, complexity and differentiation increases, as well as in the risk of conflicts, opportunistic behavior, and competing goals between subunits. As a result management is confronted by the increasingly crucial need to monitor, coordinate, and integrate the activities of the IMJV [3], [15]. A structuration process [27] develops knowledge technologies e.g., the meaning and concepts to use mechanical technologies and human technologies in production [5], by which uncertainties are 
transformed to relatively certainties of how to act. Structuration suggest, then, that systems are built from rules and interactions; that resources, like actions, are tools people use to enact organizations; and that structures are the medium and outcome of the interaction [27].

Manager are bounded rational [23] in their acting, because the continuous, reciprocal interaction among variables, have a continuum of outcomes, that should all alternatives be examined no action would occur. Manager act accordingly to what they can see and take advantage of in their belief on what is satisfyingly. They are bounded by, what they know, and by what they value, and they are sensitive to norms of what is appropriate behavior [13]. IMJV, as a synthetic organization, is without organizational rationality, because of lack of rules, routines, and procedures, and "knowing that", and "knowing how" [13], is dispersed among organizational members, without common interpretation of the world. It is left to manager 's bounded rationality to implement a structuration process, satisfying their belief on the relation between the imprented targets from partner, knowledge technologies encoded in the context, and choice of coordination tuning, to facilitate an emerging learning process with in the IMJV. The theoretical framework for the research is outlined in Figure 1.

The first category of determinants in the framework comprises two exogenous determinants of IMJV forms: technology and organization structure. Technology is linked to organization structures through its requirements for procedures to control work and requirement for information, coordination and control intensity. How managers integrate mechanical technologies with the human technologies is dependent on their choices between mechanism: formalization, to make task simpler by routinization, and building information linkages; centralization, to distribute responsibility and decisions authority; socialization, the degree of motivation of workers and reduction of distractions. The organizational absorptive capacity is thus an outcome of management's cognitive skills to combine coordination mechanisms in a structuration process and building communication linkages supporting exploration of the new possibilities.

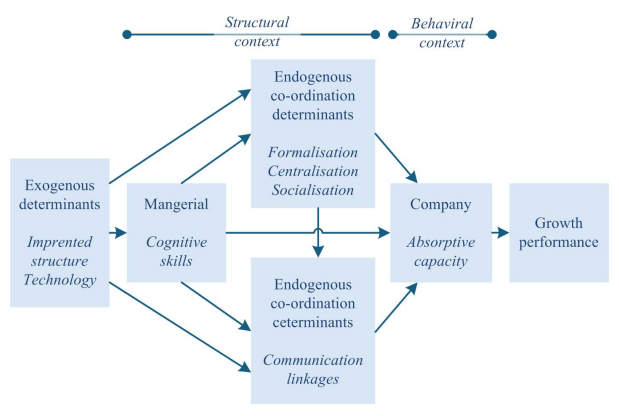

Fig. 1. Theoretical framework 


\section{Conclusion}

This conceptual approach is descriptive. The intended empirical research is case study to explore, in natural settings, how this approach might contribute to deeper understanding of the phenomenon. But much more work must be done, especially in the scientific understanding and methodology proposal.

\section{References}

1. Burgelman, R.: Design for Corporate Entrepreneurship in Established Firms. Calif. Manage. Rev. 26, 154 (1984)

2. Chandler, A.D.: MIT Press, Cambridge

3. Child, J.: Organizations: A guide to problem and practise. Harper \& Row, New York (1977)

4. Cohen, W.M., Levinthal, D.A.: Absorptive Capacity: A New Perspective on Learning and Innovation. Administrative Science Quaterly 35, 128 (1990)

5. Collin, P.D., Hage, J., Hull, F.: A framework for analyzing technical systems in complex organizations. In: Anonymous Research in the Sociology of Organizations. JAI Press, Greenwich (1986)

6. Damanpour, F.: Organizational Innovation: A Meta-Analysis of Effects of Determinants and Moderators. Academy of Management Journal 35, 555 (1991)

7. Damanpour, F., Gopalakrishnan, S.: Theories of Organizational Structure and Innovation Adoption: The Role of Environmental Change. J. Eng. Technol. Manage. 15, 1-24 (1998)

8. Eppkin, D.J.: Planning for Strategic Flexibility. Long Range Plann. 11, 9 (1978)

9. Evans, J.S.: Strategic Flexibility for High Technology Manoeuvres: A Conceptual Framework. Journal of Management Studies 28, 69-89 (1991)

10. Hage, J.T.: Organizational Innovation and Organizational Change. Annual Review of Sociology 25, 597 (1999)

11. Inkpen, P., Beamish, P.: Knowledge, Bargaining Powder, and the Instability of International Joint Ventures. Academy of Management Review 22, 177 (1997)

12. Kogut, B.: Joint Ventures: Theoretical and Empirical Perspectives. Strategic Manage. J., 319 (1988)

13. Kogut, B., Zander, U.: What Firms do? Coordination, Identity and Learning. Organization Science 7, 502 (1996)

14. Lindsay, P.H., Norman, D.A.: Human Information Processing (1977)

15. Mintzberg, H.: The structuring of organizations, a synthesis of the research. Prentice-Hall, New York (1979)

16. Mintzberg, H., Anestrand, B., Lampel, J.: The strategy safari. The Free Press, New York (2000)

17. Nielsen, K., Brunø, T.D., Jørgensen, K.A.: A Framework Study on Assessment of Mass Customization Capbilities. In: Proceedings of MCP-CE 2012, Novi Sad, Serbia (2012)

18. Nohria, N., Gulati, R.: What is the Optimum Amount of Organizational Slack?: A Study of the Relationship between Slack and Innovation in Multinational Firms. European Management Journal 15, 603 (1997)

19. Parson, T.: Structure and process in mordern societies. Free Press, Glencoe, III (1960)

20. Pine, B.J.: Mass customization: The new frontier in business competition. Harvard Business School Press, Boston (1993) 
21. Sahal, D.: Original Research ArticleTechnological Forecasting and Social Change. Technology, Productivity, and Industry Structure 1, 1 (1983)

22. Salvador, F., De Holan, P.M., Piller, F.: Cracking the Code of Mass Customization. MIT Sloan Management Review 50, 71-78 (2009)

23. Simon, H.: Economic, Bounded Rationality and the Cognitive Revolution. In: Egidi, M., Marris, R., Viale, R. (eds.). Edward Publisher, Hants (1992)

24. Teece, D.J., Pisano, G., Shuen, A.: Dynamic Capabilities and Strategic Management. Strategic Manage. J. 18, 509-533 (1997)

25. Thomson, J.D.: Organization in aaction. McGraw-Hill, New York (1967)

26. Urabe, K.: Innovation and the Japanese Mangement System, 3 (1988)

27. Weick, K.E.: Technology as Equivoque: Sensemaking in New Technologies. In: Godmand, P.S., Sproull, L.S. (eds.) Technology and Organizations

28. Wheelwright, S., Clark, K.: Competing through Development Capability in a Manufacturing-Based Organization. Bus. Horiz. 35, 29 (1992) 